\title{
Seasonal and life-stage variation in the reproductive ecology of a marine apex predator, the tiger shark Galeocerdo cuvier, at a protected female-dominated site
}

\author{
James A. Sulikowski, ${ }^{1, *}$, Carolyn R. Wheeler ${ }^{1}$, Austin J. Gallagher ${ }^{2,3}$, \\ Bianca K. Prohaska ${ }^{4}$, Joseph A. Langan ${ }^{1}$, Neil Hammerschlag ${ }^{2,5, *}$ \\ ${ }^{1}$ Department of Marine Sciences, University of New England, 11 Hills Beach Road, Biddeford, ME 04005, USA \\ ${ }^{2}$ Rosenstiel School of Marine and Atmospheric Science, University of Miami, 4600 Rickenbacker Causeway, \\ Miami, FL 33149, USA \\ ${ }^{3}$ Beneath the Waves Incorporated, Syracuse, NY 13202, USA \\ ${ }^{4}$ Florida State University, Department of Biology, King Life Sciences, 319 Stadium Dr., Tallahassee, FL 32306, USA \\ ${ }^{5}$ Abess Center for Ecosystem Science and Policy, University of Miami, 1365 Memorial Drive, Miami, FL 33146, USA
}

\begin{abstract}
Advancing our knowledge of the reproductive biology and mating systems of freeranging sharks is inherently challenging. The large size and mobility of the specimens are just a few of the problems that make such studies complicated, and in some respects, impractical. The tiger shark Galeocerdo cuvier is a large, roving, apex predator found in many oceans throughout the world. Although their nomadic nature is primarily linked to large-scale migrations, these sharks can also display site fidelity. One site where this is known to occur is at Tiger Beach, Bahamas. Unique to the waters of this area is the consistent sighting of large females. While the sex-specific use of the area remains unknown, the shallow, warm environment could represent a critical habitat for reproductive events. To investigate the reproductive biology of tiger sharks at Tiger Beach, 65 individuals were opportunistically sampled between 2011 and 2014. Reproductive status of captured females $(n=59)$ was assessed with ultrasonography and by measuring circulating sex steroid hormones (progesterone, testosterone and estradiol). Our results indicate that Tiger Beach is a high-use site for female tiger sharks of mixed life stages. The results also suggest that Tiger Beach may function as a refuge habitat, allowing females to reach maturity free from male mating harassment, as well as functioning as a gestation ground where gravid females can benefit from year-round calm warm waters, which may reduce the gestation period and accelerate embryo development.
\end{abstract}

KEY WORDS: Tiger shark $\cdot$ Reproduction $\cdot$ Ultrasound $\cdot$ Blood hormones

\section{INTRODUCTION}

Populations of many migratory marine predators such as sharks, tunas, and billfish are heavily exploited, and are exhibiting large declines across their global range (Myers \& Worm 2003, Worm et al. 2006). The potential for effective management and conser-

*Corresponding authors: jsulikowski@une.edu,

nhammerschlag@rsmas.miami.edu vation of these marine megafauna is linked to an understanding of how their behaviors relate to important oceanographic and biological processes (e.g. Costa et al. 2012). For example, information on age/size at maturity, gestation length, and seasonal reproductive cyclicity is needed for the construction of population models used in estimating sustainable

() The authors 2016. Open Access under Creative Commons by Attribution Licence. Use, distribution and reproduction are unrestricted. Authors and original publication must be credited.

Publisher: Inter-Research · www.int-res.com 
harvest levels, and for targeting the biological mechanisms of species' vulnerability (Walker 2004, 2005, Gallagher et al. 2012). Therefore, determining the reproductive biology of marine fishes and identifying key areas associated with reproduction (such as mating, gestation or parturition) have become priorities for marine conservation biology. However, these data are generally lacking for many marine fishes because of the logistical and technological challenges of working in the marine environment, in addition to those associated with studying often rare, cryptic, and highly migratory species.

Many shark species display predictable and seasonal long-distance migrations that are often associated with age and/or size-based segregation between and within the sexes (e.g. Weng et al. 2005, Domeier \& Nasby-Lucas 2012, Carlson et al. 2014). Although certain adult migrations have been linked to reproductive events (e.g. mating, parturition; Chapman et al. 2015), empirical data to support these movements in sharks are rare and have only been observed in relatively lower trophic level species. For example, the only direct evidence of shark mating-site fidelity comes from nurse sharks Ginglymostoma cirratum, whereby this species has been observed to enter warm, shallow areas of the Dry Tortugas National Park (Florida, USA) in early summer to mate (Carrier et al. 2003). In addition, the only direct evidence of parturition site fidelity in sharks comes from parental genotype reconstruction of lemon sharks Negaprion brevirostris in Bimini, Bahamas, and blacktip reef sharks Carcharhinus melanopterus in Moorea, French Polynesia (e.g. Mourier \& Planes 2013, Feldheim et al. 2014). These studies determined that adult females return to their respective nursery sites to give birth. While there have been observations of pregnant females aggregating in gestation grounds with elevated water temperatures (e.g. Bansemer \& Bennett 2009, Nosal et al. 2014), few studies have found direct evidence of habitats used by large predatory female sharks to gestate or give birth. Given the conservation importance of designating such areas, further studies on the reproductive biology of these species are warranted (e.g. Awruch et al. 2014).

The tiger shark Galeocerdo cuvier is a large (up to $5.5 \mathrm{~m}$ in length), highly migratory, apex predator found worldwide in temperate and tropical seas (Compagno 2005). Although primarily a wide-ranging oceanic species, it also occupies a variety of other habitats, including coral reefs, pelagic environments, and oceanic atolls (Heithaus et al. 2007, Meyer et al. 2009, Fitzpatrick et al. 2012, Hammerschlag et al.
2012, 2015, Hazin et al. 2013, Papastamatiou et al. 2013, Werry et al. 2014). In the western central Atlantic, there is a shallow-water area on Little Bahama Bank nicknamed 'Tiger Beach' by dive tourism operators due to the high abundance of tiger sharks found there (Gallagher \& Hammerschlag 2011). Satellite tracking data from this location have revealed that females exhibit periods of prolonged residency (up to $180 \mathrm{~d}$ ), and the majority of sharks found here are generally at or above the size of sexual maturity (>300 cm total length; Branstetter et al. 1987, Whitney \& Crow 2007). As such, it is possible that the predominately female use of this site may be related to a reproductive aspect of this species' life history, such as mating or gestating. This is of particular significance since the removal (i.e. fishing pressure), or protection (i.e. sanctuary) of reproductively active female sharks can have a disproportionate effect on population size (discussed in Shiffman et al. 2014).

In the present study, multi-year and multi-season data were opportunistically collected in order to investigate if this female-dominated site is potentially linked to reproduction. Although lethal sampling has historically been considered the most effective approach for collecting reproductive information from elasmobranch fishes, non-lethal approaches such as ultrasonography and analysis of plasma sex steroid hormones have become feasible and/or practical sampling alternatives (for review see Hammerschlag \& Sulikowski 2011). Here, we integrated physiological sampling of plasma sex steroid hormones (progesterone, testosterone and estradiol), photo-documentation of mating scars, and ultrasonography to determine the reproductive status of tiger sharks present at Tiger Beach and elucidate the potential function of this location.

\section{MATERIALS AND METHODS}

\section{Project phases}

Fieldwork was conducted at Tiger Beach $\left(26.86^{\circ} \mathrm{N}\right.$, $79.04^{\circ} \mathrm{W}$ ) over the course of 5 research expeditions: December 2011, July 2012, October 2013, May 2014, and November 2014. Data collection consisted of 2 sampling phases. In Phase I (December 2011 and July 2012), blood samples were collected from captured sharks ( $\mathrm{n}=20$; 18 females, 2 males). In Phase II, ultrasonography was added to this sampling protocol and individuals were also inspected for mating scars ( $\mathrm{n}=45$; 41 females, 4 males). 


\section{Capture and sampling}

Tiger sharks were captured using standardized circle-hook drumlines, which is a passive fishing technique (as described in Gallagher et al. 2014). Briefly, the gear consisted of a submerged weight base tied to a line running to the surface by means of an attached, inflatable buoy float. A 23 m monofilament gangion line $(\sim 400 \mathrm{~kg}$ test $)$ was attached to the submerged weight by a swivel, which terminated at a baited 16/0, 5-degree offset circle hook. This method permitted sharks to swim in a $23 \mathrm{~m}$ radius circle around the base when captured. An hour after first deployment, each drumline was sequentially checked for shark presence. Once hooked, each shark was slowly brought to the boat and restrained on a dive platform, partially submerged in the water. To facilitate respiration, an oxygen enriched water pump was immediately inserted into the shark's mouth. This capture and handling method was selected to promote shark vitality and reduce stress levels during sampling (Gallagher et al. 2014). For each individual captured, sex was recorded and stretched total length (TL) was measured to the nearest $\mathrm{cm}$ over a straight line along the axis of the body.

\section{Blood sampling}

Blood ( 20 ml) was collected from the caudal vein using 2 chilled heparinized 14 gauge needles attached to 2 separate $10 \mathrm{ml}$ plastic syringes. The heparinized blood sample was stored on ice for up to $20 \mathrm{~min}$ before being centrifuged at $3500 \mathrm{rpm}(410 \times$ $g$ ) for $3 \mathrm{~min}$. The plasma was then removed and stored frozen at $-20^{\circ} \mathrm{C}$ for future hormonal analyses.

\section{Plasma steroid hormone extraction}

Each plasma sample was extracted for progesterone $\left(\mathrm{P}_{4}\right)$, testosterone $(\mathrm{T})$, and $17 \beta$-estradiol $\left(\mathrm{E}_{2}\right)$ following protocols from Tsang \& Callard (1987) and Sulikowski et al. (2004). A $500 \mu \mathrm{l}$ aliquot of each plasma sample was extracted twice for each hormone with 10 volumes of ethyl ether (ACS grade), and the liquid phase was evaporated at $37^{\circ} \mathrm{C}$ in a heat block under a stream of nitrogen. To account for procedural loss, prior to extraction each sample was spiked with 1000 counts min $^{-1}$ of tritiated $\mathrm{P}_{4}, \mathrm{~T}$, and $\mathrm{E}_{2}$ obtained from Perkin Elmer. The extract was reconstituted in phosphate buffered saline with $0.1 \%$ gelatin (PBSG); mean recoveries of $\mathrm{P}_{4}, \mathrm{~T}$ and $\mathrm{E}_{2}$ were 59,84 , and $69 \%$, respectively.

\section{Radioimmunoassay}

Steroid hormone concentrations were determined following a modified radioimmunoassay procedure from Sulikowski et al. (2004). Non-radiolabeled $\mathrm{P}_{4}$, $\mathrm{T}$ and $\mathrm{E}_{2}$ were obtained from Steraloids. The specifics of the non-radiolabeled stock concentrations, radiolabeled steroids, antibody characteristics, and titers can be found in Sulikowski et al. (2004). A Tri-Carb 2900TR liquid scintillation analyzer (Perkin Elmer) was used to determine radioactivity. The mean intraassay coefficients of variation for $\mathrm{P}_{4}, \mathrm{~T}$, and $\mathrm{E}_{2}$ were 11,10 , and $6 \%$, and the inter-assay coefficients of variation were 13,10 , and $10 \%$, respectively. When hormone values for individual samples fell below detectable limits, those samples were concentrated and re-analyzed. When calculating mean $( \pm \mathrm{SE})$ concentrations of each steroid hormone, any value that was non-detectable after concentration was assigned the lowest possible concentration that the assay would have been able to detect in the aliquot used (e.g. Prohaska et al. 2013).

\section{Mating scars}

The body of each captured shark from Phase II was examined for evidence of mating scars and bite wounds, which were identified as distinct, semicircular marks along the flank or fins (Pratt \& Carrier 2001). Mating scars also showed clear differences in coloration and contrast when compared to the normal pigmentation of the sharks' skin; these changes ranged from minor (e.g. streak marks from single teeth, shallow punctures; Fig. 1A) to major (e.g. deep lacerations or bites exposing integument and dermis; Fig. 1B).

\section{Ultrasonography}

Ultrasonography was initiated during Phase II of the study, and was performed on the abdominal region of female tiger sharks $(n=41)$ to help assess reproductive stage. An Ibex Pro portable ultrasound (EI Medical Imaging) with a $60 \mathrm{~mm}$ curved linear array 2.5 to $5 \mathrm{MHz}$ transducer (model 290470) capable of a $24 \mathrm{~cm}$ scan depth was used to obtain images of the reproductive tract of each female. Scanning was performed on the ventral surface from the pectoral to the pelvic fin in both a transverse and longitudinal orientation to obtain cross sectional and lengthwise images, respectively. Additionally, each 

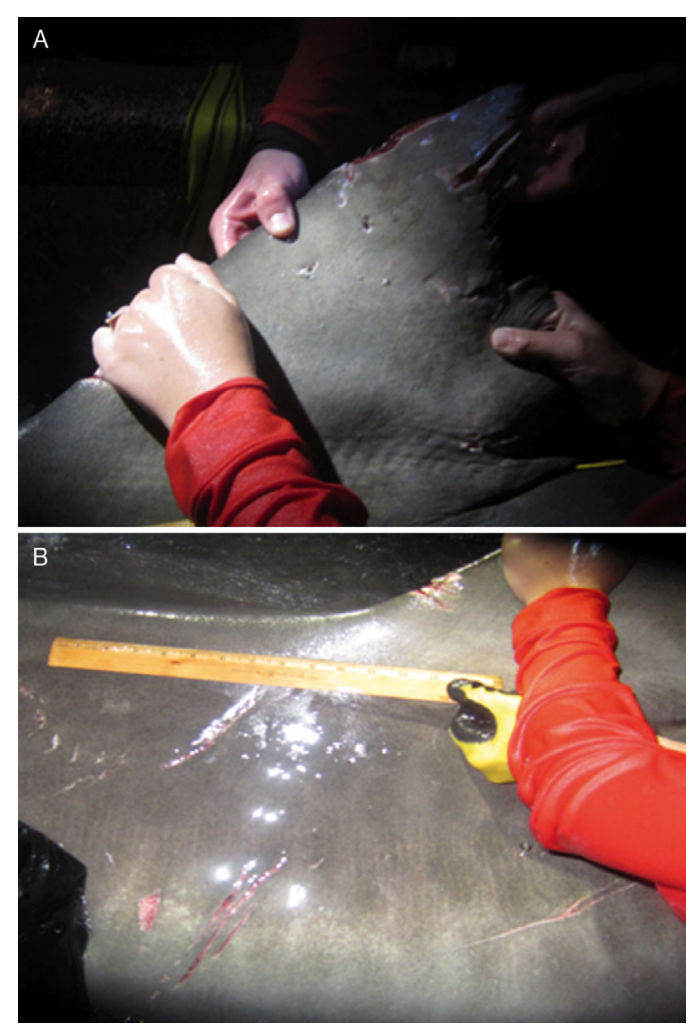

Fig. 1. Examples of mating scars observed on female tiger sharks Galeocerdo cuvier sampled at Tiger Beach, Bahamas, ranging from (A) shallow punctures to (B) deep lacerations or bites exposing integument and dermis

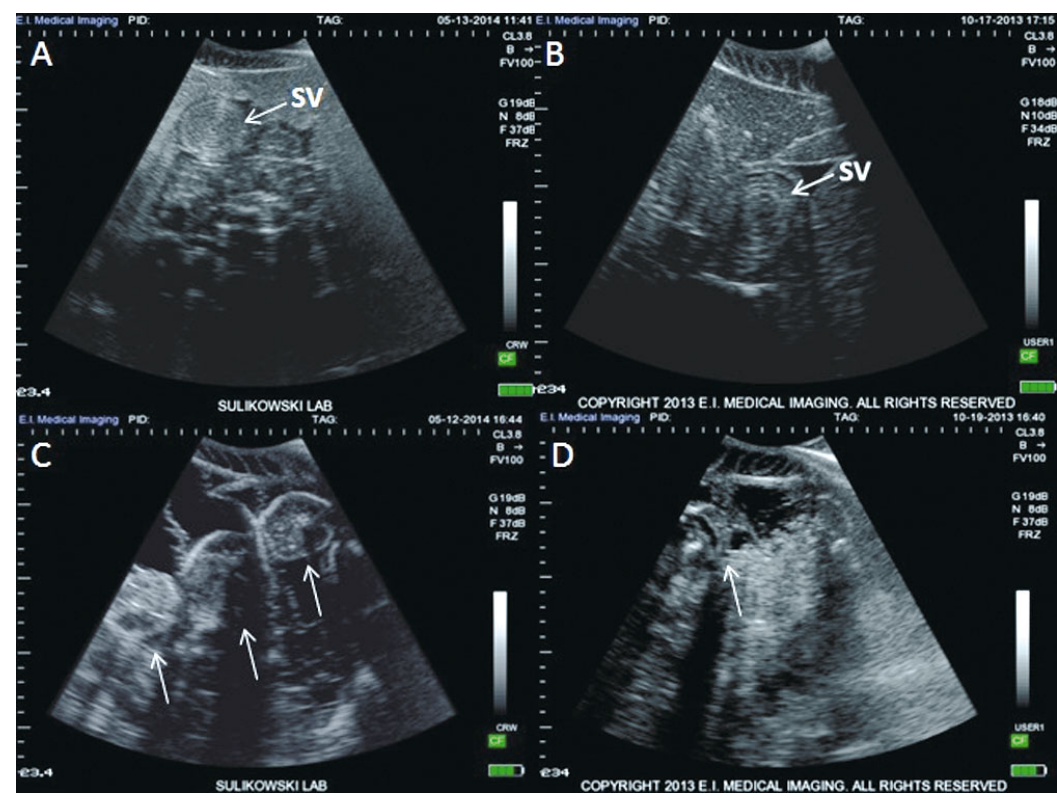

Fig. 2. Transverse ultrasound images of tiger sharks Galeocerdo cuvier obtained from (A) immature, (B) non-gravid mature and $(C, D)$ gravid females. SV: spiral value; arrows point to embryos. Note that images (A) and (B) have similar characteristics, making immature and mature non-gravid indiscernible by ultrasonography. Mature gravid individuals $(C, D)$ had easily identified embryos in utero shark was imaged between the pectoral fins to view the ovary and follicles. Gain was auto-focused by tissue composition to optimize viewing for the near and far field for each individual. Depth of the scan ranged from 12 to $24 \mathrm{~cm}$, depending on the image being obtained. Collected images and video loops were saved on the Ibex Pro at the time of sampling. Images and frozen video stills were then used to measure (via proprietary software pre-installed on the Ibex Pro ultrasound) pup diameter $(\mathrm{cm})$ along the transverse axis (Fig. 2).

\section{Determination of reproductive stage}

After all data had been accumulated and reviewed, sharks were assigned into 1 of 3 distinct reproductive stages (immature, mature non-gravid, or mature gravid) using a 4-step process. First, ultrasound data were used to determine if Phase II sharks were gravid based on presence or absence of embryos (Step 1). For non-pregnant females, ultrasonography could not differentiate between immature and mature non-gravid sharks (Fig. 2). Thus, for sharks that were not pregnant, we used TL to separate mature non-gravid from immature individuals (Step 2). Based on a review of the primary literature, female tiger sharks in the study region generally mature at $300 \mathrm{~cm}$ or greater TL (e.g. Clark \& von Schmidt 1965, Branstetter et al. 1987, Castro 2011). Thus, all Phase II sharks $\geq 300 \mathrm{~cm}$ TL and not pregnant (based on ultrasound) were categorized as mature non-gravid, and all those $<300 \mathrm{~cm}$ TL were considered immature. Once the 3 reproductive stages were assigned for Phase II sharks, blood hormone values were compared between stages for significant differences (Step 3). Since hormone values and TL were the only available criteria with which to assess reproductive stage in Phase I sharks, ensuring that hormone profiles were linked to specific reproductive events was a critical component of the study (e.g. Hammerschlag \& Sulikowski 2011). However, when the mean $P_{4}, T$, and $\mathrm{E}_{2}$ concentrations were compared among reproductive stages (1-way ANOVA followed by Tukey's HSD), hormone profiles between immature and mature gravid sharks were statis- 
tically indistinguishable $\left(\mathrm{P}_{4}: F_{2,38}=0.82, \mathrm{p}=0.45\right.$; $\mathrm{T}: F_{2,38}=3.5, \mathrm{p}=0.04 ; \mathrm{E}_{2}: F_{2,38}=11.9, \mathrm{p}<0.0001$; Fig. 3). Because of the similarities in hormone concentrations between immature and mature gravid females, it was determined that blood hormone values alone could not accurately differentiate between these two reproductive stages in Phase I sharks ( $\mathrm{n}=$ 18). Due to this unanticipated result, the final step required an additional quantitative method in order to differentiate between mature gravid and mature non-gravid individuals in Phase I sharks (Step 4). Using the collective empirical reproductive data (hormone concentrations and ultrasonography) from Phase II, a multiple logistic regression with forward

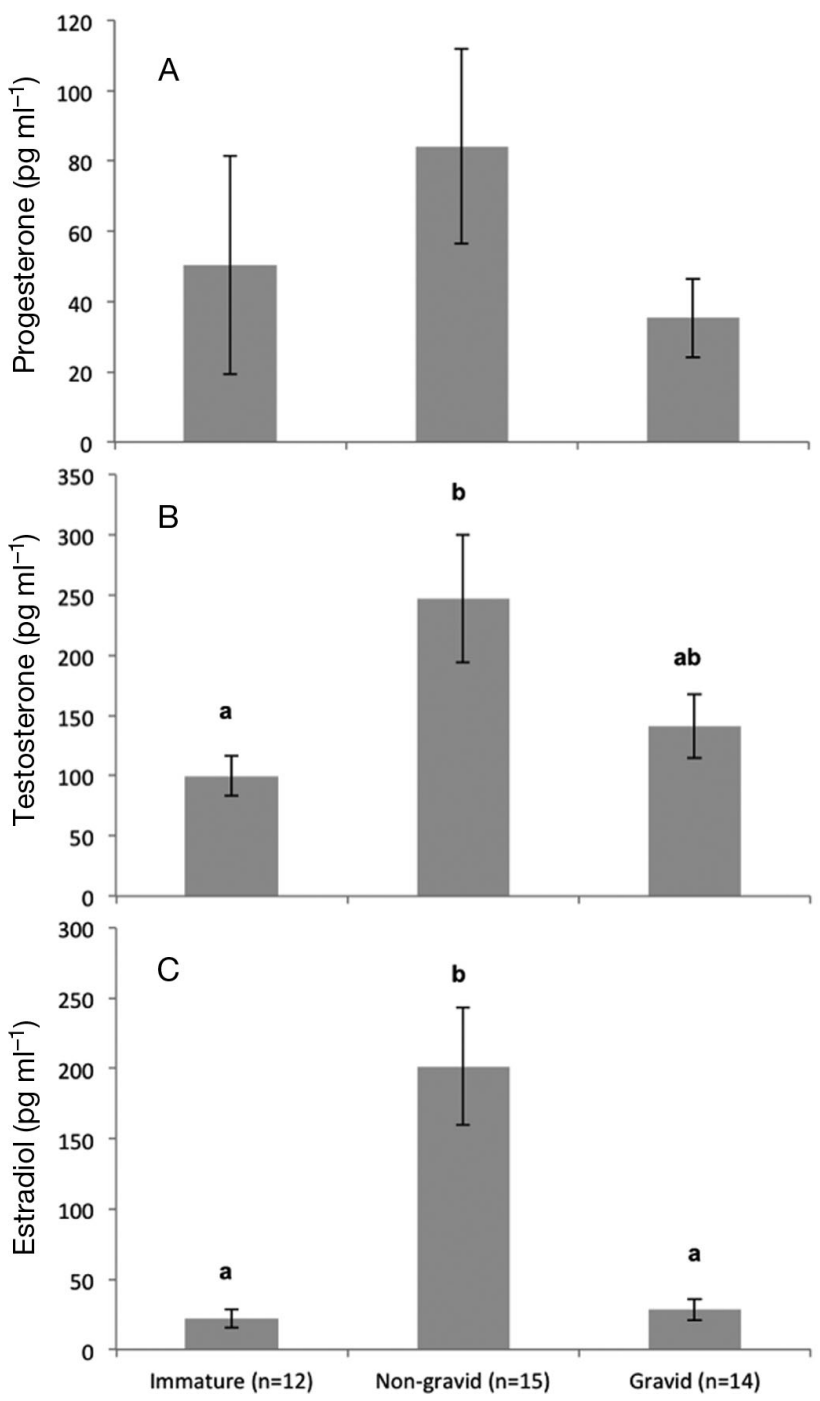

Fig. 3. Mean $( \pm \mathrm{SE})(\mathrm{A})$ progesterone, (B) testosterone, and (C) estradiol concentrations plotted by reproductive stage of Phase II female tiger sharks Galeocerdo cuvier. Lowercase letters denote statistically significant pairwise differences in hormone concentrations between stages $(p<0.05)$ selection $\left(\Delta \mathrm{AIC}_{\mathrm{c}} \leq 3\right.$; Burnham \& Anderson 2002) was generated to predict gravidity in mature $(\geq 300 \mathrm{~cm}$ TL) tiger sharks sampled during Phase I. However, the interaction between all covariates in this study showed high colinearity $\left(\mathrm{E}_{2} \times \mathrm{T}: \mathrm{r}=0.74 ; \mathrm{E}_{2} \times \mathrm{P}_{4}: \mathrm{r}=\right.$ $0.70 ; \mathrm{T} \times \mathrm{P}_{4}: \mathrm{r}=0.77$ ); therefore only the primary variables were analyzed. The resulting model fit ( $\mathrm{df}=1$; coefficient of discrimination, $D=0.67$; Tjur 2009) indicated that $\mathrm{T}$ and $\mathrm{E}_{2}$ had significant predictive value in determining the probability of gravidity in mature sharks (Table 1). The relationship between the probability of gravidity and $\mathrm{T}$ and $\mathrm{E}_{2}$ concentrations was represented by the solution to the log-odds (logit) function:

$$
\begin{gathered}
\mathrm{p}(\text { gravidity })=\mathrm{e}^{(4.321537-0.036736 \times \mathrm{E} 2-0.009116 \times \mathrm{T})} / \\
{\left[1+\mathrm{e}^{(4.321537-0.036736 \times \mathrm{E} 2-0.009116 \times \mathrm{T})}\right]}
\end{gathered}
$$

This model was then applied to concentrations of $\mathrm{T}$ and $E_{2}$ from tiger sharks in Phase I that had not been examined with ultrasonography, to determine probability of gravidity for mature individuals $(>300 \mathrm{~cm}$ TL). An individual was considered to be gravid if the logit function returned a probability $\geq 0.75$. Conversely, an individual was considered to be nongravid if the logit function returned a probability $<0.75$. Phase I individuals under $300 \mathrm{~cm}$ TL were considered immature.

Using the reproductive classifications as determined above, seasonal differences in the frequency of reproductive stages of sharks captured at the study site were analyzed with chi-squared analyses. Data were statistically analyzed using R v.2.15.2. All data were tested for normality prior to parametric analysis, and all tests were considered significant at $\mathrm{p} \leq 0.05$.

\section{RESULTS}

In total, 65 tiger sharks were captured at Tiger Beach: 6 males (mean \pm SD: $311 \pm 53 \mathrm{~cm} \mathrm{TL}$ ) and 59 females $(265 \pm 100 \mathrm{~cm}$ TL; 41 in Phase II; 18 in Phase I), generating a sex ratio (M:F) of 1:9.8.

Table 1. Model results used for determining the probability of gravidity in tiger sharks Galeocerdo cuvier. Akaike's information criterion $\left(\mathrm{AIC}_{\mathrm{c}}\right.$ ) corrected for small sample sizes

for each step lowered by $3 . \mathrm{E}_{2}$ : estradiol; $\mathrm{T}$ : testosterone

\begin{tabular}{|lc|}
\hline Hormone & $\mathrm{AIC}_{\mathrm{c}}$ \\
\hline Intercept & 42.316195 \\
$\mathrm{E}_{2}$ & 26.400483 \\
$\mathrm{E}_{2} \times \mathrm{T}$ & 22.447960 \\
\hline
\end{tabular}


Although low sample sizes precluded the use of statistical analysis, an increasing trend in pup diameter across sampling periods was observed in gravid females (Table 2). Using the fitted logit model, mature December Phase I individuals $(n=10)$ were all predicted as gravid, whereas the 1 mature shark in July was predicted as non-gravid (see Table S1 in the Supplement at www.int-res.com/articles/suppl/ b024p175_supp.pdf). Based on the collected results, the females sampled in this study consisted of 19 immature $(32 \%), 17$ mature non-gravid $(29 \%)$, and 23 mature gravid (39\%) individuals (see Table S1 for full details).

A significant difference was found in the frequency of each reproductive stage observed by month $\left(\chi^{2}=\right.$ 32.9, df $=14, \mathrm{n}=59, \mathrm{p}<0.0001$; Fisher's exact test $\mathrm{p}<0.0001$ ). When investigating the frequency of immature females observed each month, no significant difference between months was found $\left(\chi^{2}=8\right.$,

Table 2. Mean $( \pm \mathrm{SE})$ maximum pup diameter of gravid female tiger sharks Galeocerdo cuvier sampled at Tiger Beach, Bahamas during 2013 and 2014

\begin{tabular}{|lcc|}
\hline Sampling event & Mean diameter $(\mathrm{cm})$ & $\mathrm{n}$ \\
\hline Oct 2013 & $6.34 \pm 1.08$ & 7 \\
May 2014 & 6.52 & 1 \\
Nov 2014 & $6.97 \pm 2.12$ & 2 \\
\hline
\end{tabular}

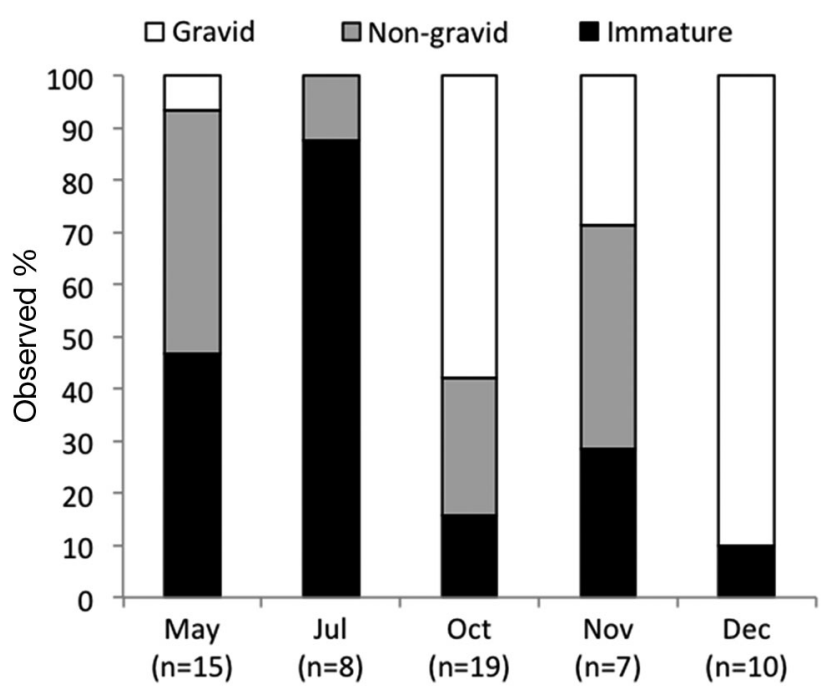

Fig. 4. Percent of female tiger sharks Galeocerdo cuvier in each reproductive stage by month. A significant difference in the observance of both non-gravid and gravid mature females by month was observed, with a higher frequency of mature non-gravid females in May, October and November, and a higher frequency of mature gravid females in October and December $\mathrm{df}=4, \mathrm{n}=19, \mathrm{p}=0.09$; Fig. 4). However, a significant difference in the observance of both non-gravid and gravid mature females by month was observed (nongravid: $\chi^{2}=10.25, \mathrm{df}=4, \mathrm{n}=17, \mathrm{p}=0.04$; gravid: $\chi^{2}=23, \mathrm{df}=4, \mathrm{n}=23, \mathrm{p}<0.001$; Fig. 4), with a higher frequency of mature non-gravid females in May, October, and November, and a higher frequency of mature gravid females in October and December. Finally, mating scars were only observed on 7 individuals, 6 of which were non-gravid females.

\section{DISCUSSION}

In this study, the use of ultrasonography was found to be an effective tool to discern pregnancy in tiger sharks. This finding is similar to studies of other large sharks where ultrasonography was determined to be effective in assessing and monitoring reproductive status (e.g. Carrier et al. 2003, Daly et. al. 2007). However, an unexpected result in our study was the difficulty in linking steroid hormone concentrations to specific reproductive periods, especially since these biomarkers have been correlated with morphological changes within the reproductive tracts of other elasmobranch species (e.g. Manire et al. 1995, Tricas et al. 2000, Sulikowski et al. 2004, Awruch et al. 2008, Prohaska et al. 2013). This was particularly problematic when differentiating between immature and mature gravid individuals regardless of the hormone analyzed. While ascertaining the mechanistic endocrine pathways of these hormones in tiger shark reproduction is beyond the scope of the current study, the apparent lack of correlation between hormonal signature and reproductive stage may be related to a sampling regime that failed to capture the transient periods in which these steroids were elevated. For example, hormone concentrations have been shown to vary widely between the different reproductive modes in elasmobranchs, between species exhibiting the same reproductive mode, and between individual species of the same genus over the course of their reproductive cycles (for a review see Hammerschlag \& Sulikowski 2011, Sulikowski et al. 2011). In addition, when compared to other yolk sac viviparous species (aplacental viviparity), the hormonal values recorded in the current study are among the lowest documented (e.g. Prohaska et al. 2013, Awruch et al. 2014). Despite these anomalies, the patterns of estradiol and testosterone levels in the current study parallel those found in other adult female non-gravid yolk sac viviparous species (e.g. Tsang \& Callard 1987, Awruch et al. 2014) in which 
these hormones are associated with follicular growth leading to ovulation (Koob \& Callard 1999, Awruch 2013). Although the role that testosterone plays in viviparous elasmobranchs remains unclear (Awruch 2013), previous research suggests that this hormone is a substrate for estradiol biosynthesis (Tsang \& Callard 1982) and is correlated with follicular development (Koob et al. 1986). Given this, our findings suggest that the collective estradiol and testosterone concentrations can be used as a predictor of gravidity in sharks $300 \mathrm{~cm}$ TL and larger.

While pregnancy status could be empirically measured by ultrasound, the use of published length at maturity data for tiger sharks $(300 \mathrm{~cm}$ TL; Clark \& von Schmidt 1965, Simpfendorfer 1992, Castro 2011) was needed to delineate if a Phase I shark was immature or pregnant in the current study. Given the considerable variation in both tiger shark growth rates (e.g. Meyer et al. 2009) and size at maturity (260 to $347 \mathrm{~cm}$ TL; Whitney \& Crow 2007, this study), we recognize that there is a certain level of uncertainty surrounding the designations as used in the current study. However, we believe our thorough review of the literature along with the data from Phase II sharks justifies our use of $300 \mathrm{~cm}$ as an appropriate length at maturity in the sampled sharks. In addition, the designation of $300 \mathrm{~cm}$ TL for maturity is approximately $65 \%$ of the maximum size for this species (Castro 2011), and is a conservative estimate that is more likely to designate mature individuals $<300 \mathrm{~cm}$ TL as immature rather than vice versa.

In the present study, although the abundance of both non-gravid and gravid mature females fluctuated by month, immature females were consistently found in association with adults at Tiger Beach. These findings are particularly interesting in that our knowledge of habitat use in sharks suggests that most species exhibit a traditional triangle framework that is often associated with segregation (by size and sex) for the majority of the year (e.g. Springer 1967, Chapman et al. 2015). While the low sample size limits any definitive comparisons to this paradigm, our observation that immature females share the sampled habitat with both gravid and non-gravid adults suggests that Tiger Beach could function as an important site for female tiger sharks at different life history stages.

While tiger sharks are provisioned by dive tourists at Tiger Beach, the large-scale movement and migration patterns of sharks from this site and other neighboring areas (Hammerschlag et al. 2012, 2015), as well as the lower prevalence of male tiger sharks at Tiger Beach, suggests that dive tourism is not prima- rily responsible for tiger shark residency at this site. In addition, the environment at Tiger Beach is a shallow (average $5 \mathrm{~m}$ deep), warm (due to its proximity to the equator), mostly homogenous sand flat with irregular seagrass patches and infrequent small patches of coral. Given that this habitat is not typically associated with the primary prey of tiger sharks (e.g. Heithaus et al. 2002), it is possible that Tiger Beach may not serve as a foraging site for this species. Although it may not be linked to foraging, Tiger Beach is situated in the lee of Grand Bahama Island, which produces relatively stable and calm water conditions year-round. Given the reported 15 mo gestation period in tiger sharks (Whitney \& Crow 2007), we suggest that gravid or recently mated female tiger sharks may be using the Tiger Beach area in part to benefit from the year-round calm warm water, which likely reduces the gestation period and accelerates embryo development. For example, while not directly measured in the current study, warm water use for gestation has been observed in several other species of gravid elasmobranchs (e.g Bansemer \& Bennett 2009, Jirik \& Lowe 2012, Nosal et al. 2014). Furthermore, the lack of males and dominance of females at Tiger Beach may reduce mating attempt harassment by males (Sims et al. 2001, Jacoby et al. 2010, Wearmouth et al. 2012). Indeed, copulation in sharks is often violent, and females can incur significant injury from mating and related attempts (Pratt \& Carrier 2001). Moreover, male sharks will often attempt to copulate with immature females (Calich \& Campana 2015). Due to the skewed sex ratio observed over in the current study, we suggest that females at different life-stages likely use the area as a refuge from males. This behavior has been observed in female nurse sharks, which have shown both avoidance and shallow water refuging from males (Pratt \& Carrier 2001). While the mating and parturition behavior of tiger sharks visiting Tiger Beach is currently unknown, Lea et al. (2015) reported that mature male tiger sharks tagged off Bermuda migrated to Bahamian waters during the winter months, leading the authors to speculate that their presence in the area was linked with mating. This coincides with the period when the highest proportion of mature females as well as those individuals with mating scars were observed at Tiger Beach. Thus, it is possible that mating occurs in the Bahamas at or near Tiger Beach during the winter months. While the absence of neonate tiger sharks at Tiger Beach suggests parturition occurs elsewhere, timing based on a gestation of around 15 mo would mean pupping occurs in late spring and summer, which coincides 
with the abundance of neonates found in the North Atlantic (Natanson et al. 1999, Castro 2011). However, additional research, including tracking pregnant females, is needed to further investigate these ideas.

The findings of the current study have conservation implications, since fishing aggregations of gravid females may pose threats to the viability and health of local and regional populations (discussed in Shiffman et al. 2014). Tiger Beach is within the boundaries of the Bahamas Exclusive Economic Zone (EEZ), where commercial longlining has been banned for decades and sharks are protected from all harvest due to the establishment of a shark sanctuary in 2011. Although the results of this study suggest that Tiger Beach is occupied by sharks of mixed lifehistory stages, it is not known how long or to what extent individuals utilize Tiger Beach or the protected Bahamian waters. If gravid females spend little time within the sanctuary and/or give birth outside the sanctuary, they may be vulnerable to exploitation when they leave the area. However, the relatively high abundance of tiger sharks in the Bahamas compared to the rest of the Caribbean (Ward-Paige et al. 2010) could be attributed in part to the protection of mature and/or gravid females in the Bahamas. As a popular dive tourism site, future research should also attempt to consider if and how tourism activities (e.g. noise, food, boats, divers) could impact shark health, reproduction, and offspring fitness (Gallagher et al. 2015). Given the unique nature of the findings presented here, further research is required in order to better understand the relationship between habitat use and the reproductive status of female tiger sharks at Tiger Beach and within Bahamian waters.

Acknowledgements. For financial and logistical support, we greatly thank the Disney Worldwide Conservation Fund, the Florida Biodiversity Institute, The SeaKeepers Society, AL Jazeera America, Jim Abernethy, Carl Hampp, Angela Rosenberg, Jim Jacoby, Joe Romeiro, Brian Skerry, and the National Geographic Society. For field support, special thanks to Christian Pankow, Emily R. Nelson, Jamin Martinelli, Duncan Irschick, Fiona Gragham, Matt Heath, Mike Black, Bill Parks, Cheryl Carroll, Jay Castellano, and Kyra Hartog.

\section{LITERATURE CITED}

Awruch CA (2013) Reproductive endocrinology in chondrichthyans: the present and the future. Gen Comp Endocrinol 192:60-70

Awruch CA, Pankhurst NW, Frusher SD, Stevens JD (2008) Endocrine and morphological correlates of reproduction in the draughtboard shark Cephaloscyllium laticeps
(Elasmobranchii: Scyliorhinidae). J Exp Zool A Ecol Genet Physiol 309:184-197

Awruch CA, Jones SM, García Asorey M, Barnett A (2014) Non-lethal assessment of the reproductive status of broadnose sevengill sharks (Notorynchus cepedianus) to determine the significance of habitat use in coastal areas. Conserv Physiol 2:cou013

Bansemer CS, Bennett MB (2009) Reproductive periodicity, localized movements and behavioural segregation of pregnant Carcharias taurus at Wolf Rock, southeast Queensland, Australia. Mar Ecol Prog Ser 374:215-227

Branstetter S, Musick JA, Colvocoresses JA (1987) A comparison of the age and growth of the tiger shark, Galeocerdo cuvieri, from off Virginia and from the northwestern Gulf of Mexico. Fish Bull 85:269-279

Burnham KP, Anderson DR (2002) Model selection and multimodel inference: a practical information theoretic approach. Springer-Verlag, New York, NY

Calich HJ, Campana SE (2015) Mating scars reveal mate size in immature female blue shark Prionace glauca. J Fish Biol 86:1845-1851

> Carlson AE, Hoffmayer ER, Tribuzio CA, Sulikowski JA (2014) The use of satellite tags to redefine movement patterns of spiny dogfish (Squalus acanthias) along the US east coast: implications for fisheries management. PLoS ONE 9:e103384

> Carrier JC, Murre FL, Walsh MT, Pratt HL (2003) Assessing reproductive potential and gestation in nurse sharks (Ginglymostoma cirratum) using ultrasonography and endoscopy: an example of bridging the gap between field research and captive studies. Zoo Biol 22:179-187

Castro JI (2011) The sharks of North America. Oxford University Press, Oxford

Chapman DD, Feldheim KA, Papastamatiou YP, Hueter RE (2015) There and back again: a review of residency and return migrations in sharks, with implications for population structure and management. Annu Rev Mar Sci 7: $547-570$

Clark E, von Schmidt K (1965) Sharks of the central Gulf coast of Florida. Bull Mar Sci 15:13-83

Compagno LJV (2005) Sharks of the world, Vol 3: Carcharhiniformes. An annotated and illustrated catalogue of the shark species known to date. FAO species catalogue for fisheries purposes No. 1. FAO, Rome

> Costa DP, Breed GA, Robinson PW (2012) New insights into pelagic migrations: implications for ecology and conservation. Annu Rev Ecol Evol Syst 43:73-96

> Daly J, Gunn I, Kirby N, Jones R, Galloway D (2007) Ultrasound examination and behavior scoring of captive broadnose sevengill sharks, Notorynchus cepedianus (Peron, 1807). Zoo Biol 26:383-395

Domeier ML, Nasby-Lucas N (2012) Sex specific migration patterns and sexual segregation for adult white sharks in the northeastern Pacific. In: Domeier ML (ed) Global perspectives on the biology and life history of the white shark. CRC Press, Boca Raton, FL, p 133-146

> Feldheim KA, Gruber SH, Dibattista JD, Babcock EA and others (2014) Two decades of genetic profiling yields first evidence of natal philopatry and long-term fidelity to parturition sites in sharks. Mol Ecol 23:110-117

> Fitzpatrick R, Thums M, Bell I, Meekan MG, Stevens JD, Barnett A (2012) A comparison of the seasonal movements of tiger sharks and green turtles provides insight into their predator-prey relationship. PLoS ONE 7: e51927 
Gallagher AJ, Hammerschlag N (2011) Global shark currency: the distribution, frequency and economic value of shark eco-tourism. Curr Issues Tourism 14:797-812

Gallagher AJ, Kyne PM, Hammerschlag N (2012) Ecological risk assessment and its application to elasmobranch conservation and management. J Fish Biol 80:1727-1748

Gallagher AJ, Serafy JE, Cooke SJ, Hammerschlag N (2014) Physiological stress response, reflex impairment, and survival of five sympatric shark species following experimental capture and release. Mar Ecol Prog Ser 496: 207-218

Gallagher AJ, Vianna GMS, Papastamatiou YP, Macdonald C, Guttridge TL, Hammerschlag N (2015) Biological effects, conservation potential, and research priorities of shark diving tourism. Biol Conserv 184:365-379

> Hammerschlag N, Sulikowski J (2011) Killing for conservation: the need for alternatives to lethal sampling for apex predatory sharks. Endang Species Res 14:135-140

- Hammerschlag N, Gallagher AJ, Wester J, Luo J, Ault JS (2012) Don't bite the hand that feeds: assessing ecological impacts of provisioning ecotourism on an apex marine predator. Funct Ecol 26:567-576

> Hammerschlag N, Broderick AC, Coker JW, Coyne MS and others (2015) Evaluating the landscape of fear between apex predatory sharks and mobile sea turtles across a large dynamic seascape. Ecology 96:2117-2126

> Hazin FHV, Afonso AS, De Castilho PC, Ferreira LC, Rocha BCLM (2013) Regional movements of the tiger shark, Galeocerdo cuvier, off northeastern Brazil: inferences regarding shark attack hazard. An Acad Bras Cienc 85: 1053-1062

> Heithaus MR, Dill LM, Marshall GJ, Guhleier B (2002) Habitat use and foraging behavior of tiger sharks (Galeocerdo cuvier) in a seagrass ecosystem. Mar Biol 140:237-248

> Heithaus MR, Frid A, Wirsing AJ, Dill LM and others (2007) State-dependent risk-taking by green sea turtles mediates top-down effects of tiger shark intimidation in a marine ecosystem. J Anim Ecol 76:837-844

- Jacoby DMP, Busawon DS, Sims DW (2010) Sex and social networking: the influence of male presence on social structure of female shark groups. Behav Ecol 21:808-818

> Jirik KE, Lowe CG (2012) An elasmobranch maternity ward: female round stingrays Urobatis halleri use warm, restored estuarine habitat during gestation. J Fish Biol 80: 1227-1245

> Koob TJ, Callard IP (1999) Reproductive endocrinology of female elasmobranchs: lessons from the little skate (Raja erinacea) and spiny dogfish (Squalus acanthias). J Exp Zool 284:557-574

Koob TJ, Tsang P, Callard IP (1986) Plasma estradiol, testosterone, and progesterone levels during the ovulatory cycle of the skate (Raja erinacea). Biol Reprod 35: $267-275$

- Lea JSE, Wetherbee BM, Queiroz N, Bernie N and others (2015) Repeated, long-distance migrations by a philopatric predator targeting highly contrasting ecosystems. Sci Rep 5:11202

Manire CA, Rasmussen LEL, Hess DL, Heuter HE (1995) Serum steroid hormones and the reproductive cycle of the female bonnethead shark, Sphyrna tiburo. Gen Comp Endocrinol 97:366-376

Meyer CG, Clark TB, Papastamatiou YP, Whitney NM, Holland KN (2009) Long-term movement patterns of tiger sharks Galeocerdo cuvier in Hawaii. Mar Ecol Prog Ser 381:223-235
Mourier J, Planes S (2013) Direct genetic evidence for reproductive philopatry and associated fine-scale migrations in female blacktip reef sharks (Carcharhinus melanopterus) in French Polynesia. Mol Ecol 22:201-214

- Myers RA, Worm B (2003) Rapid worldwide depletion of predatory fish communities. Nature 423:280-283

Natanson LJ, Casey JG, Kohler NE, Colket T IV (1999) Growth of the tiger shark, Galeocerdo cuvier, in the western North Atlantic based on tag returns and length frequencies; and a note on the effects of tagging. Fish Bull 97:944-953

> Nosal AP, Caillat A, Kisfaludy EK, Royer MA, Wegner NC (2014) Aggregation behavior and seasonal philopatry in male and female leopard sharks Triakis semifasciata along the open coast of southern California, USA. Mar Ecol Prog Ser 499:157-175

Papastamatiou YP, Meyer CG, Carvalho F, Dale JJ, Hutchinson MR, Holland KN (2013) Telemetry and random walk models reveal complex patterns of partial migration in a large marine predator. Ecology 94:2595-2606

Pratt HL Jr, Carrier JC (2001) A review of elasmobranch reproductive behavior with a case study on the nurse shark, Ginglymostoma cirratum. Environ Biol Fishes 60:157-188

Prohaska BK, Tsang PCW, Driggers III WB, Hoffmayer ER, Wheeler CR, Brown AC, Sulikowski JA (2013) Assessing reproductive status in elasmobranch fishes using steroid hormones extracted from skeletal muscle tissue. Conserv Physiol 1:cot028

Shiffman DS, Gallagher AJ, Wester J, Macdonald CC, Thaler AD, Cooke SJ, Hammerschlag N (2014) Trophy fishing for species threatened with extinction: a way forward building on a history of conservation. Mar Policy 50:318-322

Simpfendorfer C (1992) Biology of tiger sharks (Galeocerdo cuvier) caught by the Queensland shark meshing program off Townsville, Australia. Aust J Mar Freshw Res 43:33-43

Sims DW, Nash JP, Morritt D (2001) Movements and activity of male and female dogfish in a tidal sea lough: alternative behavioural strategies and apparent sexual segregation. Mar Biol 139:1165-1175

Springer S (1967) Social organization of shark populations. In: Gilbert PW, Mathewson RF, Rall DP (eds) Sharks, skates and rays. Johns Hopkins University Press, Baltimore, MD, p 149-174

Sulikowski JA, Tsang PCW, Howell HW (2004) An annual cycle of steroid hormone concentrations and gonad development in the winter skate, Leucoraja ocellata, from the western Gulf of Maine. Mar Biol 144:845-853

Sulikowski JA, Williams LJ, Domeier ML (2011) The potential use of non-lethal techniques to assess the reproductive biology of the white shark, Carcharodon carcharias. In: Domeier ML (ed) Global perspectives on the biology and life history of the great white shark. CRC Press, Boca Raton, FL, p 467-478

> Tjur T (2009) Coefficients of determination in logistic regression models-a new proposal: the coefficient of discrimination. Am Stat 63:366-372

Tricas TC, Maruska KP, Rasmussen LEL (2000) Annual cycles of steroid hormone production, gonad development, and reproductive behavior in the Atlantic stingray. Gen Comp Endocrinol 118:209-225

Tsang P, Callard IP (1982) Steroid production by isolated skate ovarian follicular cells. Bull Mt Desert Isl Biol Lab 22:96-97 
Tsang PCW, Callard IP (1987) Morphological and endocrine correlates of the reproductive cycle of the aplacental viviparous dogfish, Squalus acanthias. Gen Comp Endocrinol 66:182-189

Walker TI (2004) Management measures. In: Musick JA, Bonfil R (eds) Technical manual for the management of elasmobranchs. FAO Fish Tech Pap No. 474. FAO, Rome, p 285-321

Walker TI (2005) Reproduction in fisheries science. In: Hamlett WC, Jamieson BGM (eds) Reproductive biology and phylogeny of Chondrichthyes (sharks, batoids and chimaeras). Science Publishers, Enfield, NH, p 81-126

Ward-Paige CA, Mora C, Lotze HK, Pattengill-Semmens C, McClenachan L, Arias-Castro E, Myers RA (2010) Largescale absence of sharks on reefs in the greater Caribbean: a footprint of human pressures. PLoS ONE 5: e11968

Editorial responsibility: Christine Paetzold, Oldendorf/Luhe, Germany
Wearmouth VJ, Southall EJ, Morritt D, Thompson RC, Cuthill IC, Partridge JC, Sims DW (2012) Year-round sexual harassment as a behavioral mediator of vertebrate population dynamics. Ecol Monogr 82:351-366

Weng KC, Castilho PC, Morrissette JM, Landiera-Fernandez A and others (2005) Satellite tagging and cardiac physiology reveal niche expansion in salmon sharks. Science 310:104-106

Werry JM, Planes S, Berumen ML, Lee KA, Braun CD, Clua E (2014) Reef-fidelity and migration of tiger sharks, Galeocerdo cuvier, across the Coral Sea. PLoS ONE 9:e83249

> Whitney NM, Crow GL (2007) Reproductive biology of the tiger shark (Galeocerdo cuvier) in Hawaii. Mar Biol 151: 63-70

> Worm B, Barbier EB, Beaumont N, Duffy JE, Folke C (2006) Impacts of biodiversity loss on ocean ecosystem services. Science 314:787-790

Submitted: June 4, 2015; Accepted: January 5, 2016 Proofs received from author(s): January 26, 2016 